This item was submitted to Loughborough's Research Repository by the author.

Items in Figshare are protected by copyright, with all rights reserved, unless otherwise indicated.

\title{
"Sofa and Facebook or tent and Syntagma": understanding global resistance movements from Syntagma to Tahrir
}

\section{PLEASE CITE THE PUBLISHED VERSION}

http://dx.doi.org/10.1080/23340460.2016.1154350

\section{PUBLISHER}

(c) Taylor \& Francis

\section{VERSION}

AM (Accepted Manuscript)

\section{PUBLISHER STATEMENT}

This work is made available according to the conditions of the Creative Commons Attribution-NonCommercialNoDerivatives 4.0 International (CC BY-NC-ND 4.0) licence. Full details of this licence are available at: https://creativecommons.org/licenses/by-nc-nd/4.0/

\section{LICENCE}

CC BY-NC-ND 4.0

\section{REPOSITORY RECORD}

Bilgic, Ali. 2019. "“'sofa and Facebook or Tent and Syntagma”: Understanding Global Resistance Movements from Syntagma to Tahrir". figshare. https://hdl.handle.net/2134/24252. 
"Sofa and Facebook or tent and Syntagma": understanding global resistance movements from Syntagma to Tahrir

\section{Ali Bilgic}

\section{Accepted Version}

This article proposes a conceptual understanding of contemporary protest movements that are sporadically spreading from Argentina to Armenia, and from Spain to Turkey. The challenge of performing such a conceptual discussion helping scholars to conceptualize the new movements, while remaining true to the phenomenon it aims to understand theoretically. In other words, the conceptualization should remain multifaceted, dynamic, transformative, pluralist, and conducive to the effective integration of local conditions. To this aim, instead of adopting a deductive understanding, the conceptual guideline proposed below starts from the basic unit of the movements, 'the individual'. Individuals of difference subjectivities who represent different, sometimes contending, identities come together in these movements where heterogeneity is blended with non-hierarchical politics. They risk their bodies, like the human-wall experience, as part of their resistance methods. Moreover, they form novel relations with the space they 'occupied'. The collectivity of the movement is enabled through a combination of individual decisions and performances to protest and through their ways of respatializing squares, stress, parks, and buildings as 'the home of resistance': an alternative space of politics. The argument is that the contemporary protest movements can be understood from a conceptual perspective that effectively integrates individuals (their minds and bodies) and spaces to the approach of 'multitude'.

The argument will be unfolded in three steps. The first section, entitled 'Minds and Bodies of Resistance', explores resisting individuals as cognitive and material beings with the acknowledgement of their multiple subjectivities. In the second section, the relationship between resisting individuals and space of resistance will be unpacked. It will be highlighted that the contemporary resistance movements develop a novel relationship with the space they occupy by 
respatializing it as 'home of resistance'. This space, without which the movement's claim for politics is deeply weakened becomes the constitutive trope of the movement's collective being. This collective dimension will be analysed in the last section by answering the question of what type of collectivity these resisting individuals construct. Comparing two main approaches, 'radical democratic' and 'multitude', it will be argued that multitude approach can be adopted to understand collectivity, if it is rethought by inclusion of individuals and spaces into it.

\section{Minds and Bodies of Resistance}

Neoliberal political economy is entangled by its contradictions. Increasing educational opportunities producing unemployed graduates, the idea of a borderless world with its companion of xenophobia and anti-immigration ideologies, the encouragement of both individual freedoms (from minority to LGBTQ rights) and conservative ideologies, are just to name a few. In other words, there is a strong case for 'immanent critique' in a Horkheimerian sense. However, the blurred boundaries between the right and the left, subsumed under the universality of liberal and rationalist individualism and free-market economy-as put by Mouffe, and the left's fatalism about 'capitalist realism' (Mason, 2013: 28) has depoliticized individuals en masse. This has also been exacerbated by the co-option of democratic struggles by the neoliberal Empire and its postmodern cultural ideology that individualizes humans and removed the possibility of solidarity, as argued by Hardt and Negri.

Political and intellectual apathy and fatalism have resulted in lack of 'responsiveness'. 'From an Arendtian perspective, the most fundamental threat to democratic political activity lies in the loss of responsiveness to events: the erosion of the contexts in which action makes sense' (Markell, 2010: 79). For Arendt, action and politics are intrinsically connected. 'With word and deed we insert ourselves into the human world, and this insertion is like a second birth...To act, in its most general sense, means to take an initiative, to begin, to set something into motion', Arendt argues (1998: 176177). Without action, democratic politics can be replaced by totalitarianism, which destroys the basic human condition: pluralism. Through the new protest movements, individuals who were estranged 
by the lack of responsiveness of conventional politics to its actors, institutions, methods, and ideologies, have inserted themselves into the human world globally, taken an initiative, and begun something new. Recalling Mouffe's radical democracy, politics is returned through global resistance movements in their plurality. The first conceptual question hereby is how to conceptualize the protestors as 'individuals'.

With the objective of avoiding any type of universal essence for protesting individuals' cognitive dimensions (i.e. rational, liberal, or Western), two concepts that Arendt underlines in her political philosophy can be useful: thinking and natality (Bilgic, 2015a: 277). The first concept to which Arendt gives immense role is thinking. In her 1971 lecture, 'Thinking and Moral Considerations', Arendt explained thinking as one's silent intercourse with oneself (1971: 422). This is a basic human faculty, whereas not all humans practice this faculty (such as Adolf Eichmann) so they uncritically accept structures and processes that obscure human freedoms and dignity. That is how 'evil' becomes banal: with the contribution of thoughtlessness, and subsequently lack of responsiveness, discussed above. Surely, thinking does not provide peace. It is rather discomforting and susceptible to cynicism; yet it is 'the effort to undo systems by continuous questioning' (Kateb, 2010: 38). The practice of the faculty of thinking enabled Mouheb Ben Garoui from Tunisia to join the resistance in 2011. He grew up with the fear that if one criticizes the regime, s/he is sent the place 'behind the sun' (Garouti, 2010: 48-56). Similarly, an 'accidental activist' in her own words, Lisa Epstain (2010: 189-201) became an 'occupier' in the USA through critical reflection.

For Arendt, as Berkowitz (2010: 5) puts it, thinking 'is the only reliable safety net against the increasingly totalitarian or even bureaucratic temptations to evil that threaten the modern world'. Neither democratic institutions nor appeals to universal moral rights such as equality of humans are sufficient to prevent systems from leaning towards oppression. Only thinking individuals can, because the use of this faculty can lead to 'action'. In other words, one's dialogue with oneself can lead to dialogue with others through words and deeds in 'space of appearance'. 'The fact that man is 
capable of action means that the unexpected can be expected from him, that he is able to perform what is infinitely improbable', Arendt argued in The Origins of Totalitarianism (1976: 178).

To act as to begin something anew points to the second concept of Arendt for understanding protesting individuals. This concept is natality, which refers to 'the capacity [of individuals] of beginning something anew, that is, of acting' (Arendt, 1998: 9). Natality, which starts biologically at birth, points to the potential of individuals to take initiative, to act, to start something new socially, 'as a second birth' through action (Gordon, 2002: 139). According to Arendt, each human being has 'the capacity to initiate a new set of words and actions that are uniquely hers and that no human life can ever be the replica of any other' (Benhabib 2010: 5). Natality points to a potential that can be realized politically if thinking individuals act. This potential concerns the capacity of each individual to bring something anew to the 'space of appearance'; and for this reason, this space is pluralistic. Any attempt to suppress this pluralism derived from natality through imposing a certain hegemonic identity must utilize methods of violence.

Arendt's political philosophy underlines a human faculty (thinking) and a human capacity (natality) to shed light on politics that is true to the human condition of pluralism. With regard to contemporary global resistance movements, individuals in action practice politics in plurality and reject the passivity and apathy of the last decades. As Arendt frees politics from ideological and abstract ideas and redefines it as 'action', 'post-politics' of neoliberal age has been politicized through the words and deeds of protestors (Mavrammotis, 2015: 433). In their interaction with others, thinking enables them to reflect on themselves too, as will be seen below. That said, Hannah Arendt's political philosophy shares the modern 'scientific' fallacy that prioritizes 'cognitive' before 'body'.

However, in contemporary global resistance movements, materialities of resistance, meaning bodies and spaces, are constitutive to resistance. Following from Judith Butler (2011), bodies can reproduce or challenge the relations of domination. In specific relation to protests, Sasson-Levy and Rapoport (2003) compared two social resistance movements in Israel, which challenged national security and 
gender relations. Among the two, in the Women in Black movement bodies were not tools that carried a political message, but were the political message. Their in-depth analysis revealed that rather than being a mere tool, the body is mutually constitutive of social meanings; it reflects and reproduces values and ideas; and more importantly, the 'protesting body' is a site of resistance, such as the human walls of Tahrir and Gezi. 'The body produces, elaborates, and articulates political ideologies. It does not only serve as a medium for change, but also realizes it' (Sasson-Levy and Rapoport, 2003: 399). The protesting bodies in Tahrir, Gezi, or Wall Street were not simply tools, or carriers, of protestors' different identities and ideologies. Their bodies, which occupied, read books, danced, cleaned, prayed, and performed other 'everyday' activities as new resistance methods, were the material political message: bodies surviving, living, flourishing in solidarity.

Focusing on the diverse groups of the protesting collectivity, the importance of the bodies is crystallized further. For example, regarding the human wall built by Coptic Christians in Tahrir surrounding the praying Muslim protestors, bodies became the political message of emerging solidarity within the pluralist collectivity. Another example is the bodily presence of LGBTQ members in Gezi/Taksim that destabilized not only the authorities resisted, but also other members of the protesting collectivity. 'When bodies hit the street en masse to oppose the status quo, their power can appear either infinitesimal or so spectacular [so] as to arrest onlookers in their tracks' (Eileraas, 2014: 40). The experiences in Gezi strongly underlined the importance of bodies in resistance transcending stereotypes and hostility that members of LGBTQ often experience in Turkey. The LGBTQ community indeed appeared to earn respect through bodily resistance:

The so-called "sissy boys" who carried the wounded ones out of the clash zones, the previously slanged transwomen who supplied medicine and food to the barricades, and "fags" who apparently showed the courage to sit in front of the police water cannon trucks like all those "tough guys," all gave rise to a substantial crack in hate speech, and the homophobic and transphobic collective memory woven by it within and hopefully somewhere out of the space of the resistance (Daloğlu, 2013).

LGBTQ members' bodily presence and the performances and rendering of their bodies as a site of resistance contributed to dismantling identitarian dichotomies. Furthermore, they constituted a 
discomforting reminder of other members' protesting collectivity: a motivation for thinking, a selfdialogue that reminded them of the pluralism of the human condition.

\section{Spaces of Resistance}

It is not a mere coincidence that the contemporary protest movements are often identified with local spaces. 'Wall Street' in USA, 'Millbank' in the UK, 'Tahrir' in Egypt, 'Pearl Roundabout' in Bahrain, 'Syntagma' in Greece, 'Gezi Park' and adjoined 'Taksim Square' in Turkey, and 'Puerto del Sol' in Spain were not simply public spaces that hosted the protests. This perspective, which ignores the materiality of space in politics, does not recognize how 'the space' and the protest movement are in a mutually constitutive relationship. While the movements respatialize squares, parks, libraries, and buildings and transform their social and political meanings from dehumanized and depoliticized materiality to a home of resistance, the space provides a shared identity for the resistance, which involves diverse subjectivities and identities. It can be argued that these spaces are Arendtian 'spaces of appearance' in which thinking individuals act in concert. However, as Butler (2011) argues, the Arendtian prism does not help to conceptualize the constitutive relationship between the space and movement, or how the materiality of 'space of appearance' takes part in the resistance.

The role of space in contemporary global protest movements can be approached conceptually from different angles. Firstly, as Butler (2011) argues, bodies on the street 'redeploy [public] space in order to contest and negate the existing forms of political legitimacy'. 'Occupied' spaces such as Wall Street, Tahrir, Millbank or Taksim, share a basic characteristic: they are the spaces through which the hegemonic neoliberal political and economic structures in different countries are reproduced and legitimized. In this social production process, these spaces are dehumanized or open to a few who can contribute to the reproduction of the neoliberal-conservative hegemony. Through the occupation of these spaces, the protestors do not only act in defiance. They also-and more importantly-challenge the legitimacy of political and economic systems. This challenge has three

components. Firstly, the protestors interrupt the process of legitimation by occupation. Secondly, 
they attract global public attention to the spaces where neoliberal Empire is reproduced in local contexts. Finally, they contest the legitimacy of Empire by repoliticizing the space and appropriating it as a legitimization platform of the resistance. This is why it is possible to call this 'the struggle for the space' (Harvey, 163). This struggle concerns what the resistance is about.

Another perspective for thinking about space is that the protest movements need alternative spaces to perform politics, for 'exodus' of Hardt and Negri. The occupied spaces not only provide a material platform for alternative politics, but also through this materiality they become the embodiment of alternative ways of performing politics, or, 'multitude form' (see below). One of the most important reasons for the movements was the dissatisfaction of the protestors with the conventional platforms of politics such as political parties, parliaments, and international structures of political-economic governance (i.e. IMF, World Bank). This can be partially explained by the blurring boundaries between the left and right and the apathy of the former, as discussed above. However, this does not necessarily mean that an alternative left-wing party would capture the protests. We are reminded by Saul Newman (2014: 99) that the new movements mainly reject identifiable interests, political hierarchical leadership, or party discipline. He continues, 'Nor does it seek to participate in state power, or even to take it over in some revolutionary sense, but to foster autonomous relations and ways of being in the here and now'. At least, not in the current format...Probably, the most explicit articulation of dissatisfaction towards political parties was the Spanish slogan in Puerto del Sol, 'You don't represent us'.

Similarly, the protest movements could not be conceptualized comfortably within the existing (and hegemonic) understanding of 'civil society'. Liberal understanding of civil society-recently co-opted by neoliberalism - operates through 'individuals, who are included as agents in civil society who buy, sell, and contract' not as members of collective solidarity movements (Dean, 2014: 81). Adopting the false dichotomy between individualism and collectivism where the latter is essentially deemed undesirable in favor of universality of rational individualism (Mouffe, 2005: 9-22), neoliberal civil 
society produces 'homo economicus', a 'market man' stripped from the ties of solidarity with other individuals from different subject positions. Civil society, therefore, is constructed and appropriated in diverse local contexts by maintaining the hegemony of liberal politics and free market capitalism, accompanying the state, or even 'absorbed into the state' so that 'the new rules of subordination and the disciplinary capitalist regimes are extended across the entire social terrain' (Hardt and Negri, 2000: 243). Funders from the Global North, be it the World Bank or the European Union, engineer such a neoliberal political project and co-opt local resistance movements into it (Merz, 2013: 136138). By challenging this neoliberal hegemony over society, the contemporary global protest movements have potential to democratize civil society by opening it up to pluralism and agonistic politics, as radical democratic theory argues, but also solidarity of differences (Brown, 2013: 159).

The need to challenge the legitimacy of existing systems and design a new space of politics for the resistance led the protest movements to develop a novel relationship with the space they occupied. They respatialized the material 'space of appearance' as a home of resistance. The expression of 'home' is not chosen to romanticize the protests, but to underline two novelties that appear in global protest movements, especially those whose identity was constructed through a square such as Tahrir in Egypt, Taksim in Turkey, Puerte del Sol in Spain, and Syntagma in Greece. First, when occupied by the protestors, these squares were respatalized as a communal, shared area not through conventionally political resistance methods (i.e. sit-ins, chanting slogans) but through 'everyday' performances of individuals (Bilgic, 2015a: 274). Eating, reading, praying, and cleaning are some basic everyday performances conducted communally in a shared space. A protestor from Puerto del Sol explained the transformation as follows:

As time went on, there were various kitchens and first aid stations, bathrooms, solar panels, information booths, and media relations booths. There were spaces for artistic creation, a library filled with sofas and armchairs found on the streets, and even a place for children. Some friends made a little garden next to the fountain of the Puerto del Sol. We created a small town built by the people, for the people, and there it stayed for a month (Bellver, 2013: 115). 
These 'everyday' practices are the most important tools to redefine the relationship between the space and the protest movement. When the space is converted into a collective home of diverse individuals, the 'everyday' is the performance of forming non-hierarchical relations among these individuals. Everybody can get involved in 'everyday' on the basis of the principle of equality as if they are at home. In the case of Tahrir, according to one protestor, this non-ideological, nonhierarchical, and egalitarian simplicity was quite helpful to show to the rest of the population that the protestors were 'like them', and motivated some to join the protest:

When people came to the square, they weren't just protesting against the Mubarak regime. They immediately became involved in the clean-up crew, or with the sign painters, or setting up tents, or on a security detail. Many people who were not affiliated with any party or association joined us in this way (quoted in Hirschkind, 2012: 922).

The second novelty of the protest movements' ability to construct a home of resistance concerns that 'the everyday' removes the modern political dichotomy between the public and private. Regarding the Occupy movements, Kohn (2013: 106) argues that the occupation does not simply concern taking the control of a space, but a struggle to re-claim the public through appropriating the physical space as 'sites of deliberation, community, and political activity'. The reappropriated public space of the protest movements is constructed through ostensibly apolitical performances that conventionally belong to the private sphere, such as eating, cooking, cleaning, dancing, and reading. In their attempts to design the alternative political space discussed above, the negation of the publicprivate dichotomy results from the introduction of the everyday performances as novel resistance methods. This can be interpreted as the new protest movements' global non-strategized strategy to refuse to deal with the power in power's terms. Not only the governmental authorities, but also some protestors were surprised (Rashed, 2011: 25).

\section{Rethinking the Multitude: A Question of Collectivity}

It has so far been argued that in order to conceptualize the contemporary protest movements, individuals and the novel relationship between space and movements should be rethought. 
However, this would be an incomplete conceptualization without dwelling on the thorny question regarding the communal character of the movements. Thinking individuals construct relations with each other in the respatialized, occupied squares where 'the everyday' practices form egalitarian links between them in spite of their differences-both in terms of their multiple subjectivities, and in terms of the identities they represent. One observer and protestor reflected on the Tahrir protests, and argued that protestors formed 'a functioning social universe, a temporal community' (Rashed, 2011: 22). How can we think about this 'temporal community' without abandoning the heterogeneity of the movements, while acknowledging the new relations between individuals that repair the solidarities targeted by neoliberal political economy?

There are two contending ways of conceptualization of the collectivity of protestors, each of which has a merit to underline a dimension of these new social groups: the radical democratic approach and the multitude approach. The former is based on the Schmittian understanding of politics, according to which dichotomies are the essential core of politics and the problem of liberal (and then neoliberal) politics is the imposition of universal rational individualism that assumedly eradicate differences, which are consequently expressed as extremist political movements such as the neofascist right. Instead, it is proposed that the agonistic core of politics, which is acknowledged as the dichotomy between 'the self' and 'the other' cannot be transcended. The challenge is to create political systems in which agonistic politics are accepted so that relations between 'enemies' can be converted into those between 'adversaries' (Mouffe, 2005: 4-5). Differences co-exist in 'the chain of equivalence among democratic struggles' (Laclau and Mouffe, 2001: 127-134).

In relation to the contemporary protest movements, the radical democratic approach is mainly operationalized with the objective of conceptualizing the pluralism and heterogeneity of the movements (Rancière, 2010; Inceoğlu, 2014). As opposed to the thinking of multitude (see below), it is argued that 'the people' (particularly Rancière) capture better this pluralism by underlining agonism between the protestors. Agonistic politics, however, does not presume conflict and 
antagonism, but it is a concern for understanding and negotiation with 'the other'. In the new political spaces, individuals negotiate and hear 'the others'; in this way, they can form a solidarity movement without imposing certain political projects onto 'the others'. A new political identity resembling radical democratic citizenship can be observed in these movements.

The radical democratic approach has certain advantages in conceptualizing the heterogeneity of the movements. To understand the protest movements theoretically, it is of utmost importance not to start with the inaccurate assumption that the protestors are united with collectively identifiable political objectives, or shared ideological identity, or class background. It is also equally problematic to assume that through interaction, the movement can become a unified body through the harmonization of identities and interests of the protestors. The collectivity needs a constant reproduction through negotiation and hearing between individuals with different subjectivities. The radical democratic approach enables scholars to understand this dynamism and constant need for reproduction of the collectivity. Paraphrasing what Mouffe argued for radical democracy as 'a democracy to come', the collectivities of protest movements are always 'to come'. Their ontology is simply ephemeral. In other words, there is no community, but communitycraft. Notwithstanding this contribution, the radical democratic approach begs the question of whether it is possible to conceptualize relations between individual protestors as a dichotomy between 'the self' and 'the other'; can they be conceptualized as 'adversaries'?

The second contending approach concerns Hardt and Negri's conceptualization of the collectivity as 'multitudes'. Multitude is, as Hardt and Negri (2004: xiv) argue, 'an open and expansive network in which all differences can be expressed freely and equally, a network that provides the means of encounter so that we can work and live in common'. Multitude, in other words, is a pluralistic network that enables multiple encounters and, therefore, enhances the possibility of taking action collectively while negating the existing patterns and sources of legitimacy of Empire. In fact, similar to the radical democratic collectivity, multitude is also dynamic and social; it needs individuals' agency 
to reproduce itself. In the end, it is 'the living alternative that grows within Empire' (Hardt and Negri, 2004: xiii, emphasis added). However, without essentializing it through agonistic politics looking for 'the other' to negotiate or becoming identifiable and institutionalized class, the multitude reflects 'the human condition' of plurality and natality of Arendt more than its alternatives. Multitude as 'a non-totalizable body composed of singularities' (Day and Montgomery, 2014: 52) is repeatedly reproduced anew and host potentials through words and deeds of thinking and interacting individuals.

When multitude has been criticized for the overreliance on the decision-making and acting capacity of such a phenomenal entity (i.e. Žižek, 2008: 368-370, in particular), Hardt and Negri (2012: 91), in their operationalization of multitudes (note the plurality of the concept) in the global protest movements, put such horizontal and non-hierarchical ways of performing political action is multitudes' source of power. They use the example of indignados in Spain and their decision not to participate in the 2011 elections, and being accused of 'dividing the left'. However, they argue that indignados refused to reproduce the neoliberal politics of which so-called socialist and social democratic parties are part, rather than alternatives to. In the words of Hardt and Negri (2012: 45), 'the indignados think of this as a destituent rather than a constituent process, a kind of exodus from the existing political structures.' The exodus does not refer to a refusal of engaging with politics; instead it is a firm rejection of dealing with the existing forms of politics.

While the radical democratic approach offers better conceptual guidance to understand pluralism of the protest movements, and serves as a constant reminder for scholars about their pluralism, the multitude approach provides an explanation about how political cooperation and action within such heterogeneous movements can be realized. Hardt and Negri (2011) argue that 'the clearest clues lie in the internal organization of the movements themselves - specifically, the way the encampments experiment with new democratic practices. These movements have all developed according to what we call a "multitude form" and are characterized by frequent assemblies and participatory decision- 
making structures'. Such horizontal and non-hierarchical politics was the common global practice in Tahrir, Sytagma, Gezi, and Puerto del Sol where decisions were made collectively. In the forums, an Arendtian understanding of equality was operationalized. In Arendtian understanding of collective action, 'no one is above the debate and no one's contributions are beneath the attention of others' (Waldron, 2010: 32). As one protestor stated in Syntagma (2011), 'many immigrants took the microphone and were warmly applauded', when the neo-fascist Golden Dawn was feeding the antiimmigrant attitude in Greece (Papahadjis, 2012: 162). Through this non-hierarchical practice operated on the principle of equality, collectivity as a multitude is (re)constructed. That said, the approach of multitude does not effectively conceptualize the 'individuals' of the multitude and how they form a new relationship with the space. As a result, the way in which horizontal and nonhierarchical politics are brought life and the manifestation of multitudes through their constituents remain conceptually unexplored. In other words, the multitude needs human faces.

In addition to the contributions of the radical democratic and multitude approaches, in order to conceptualize the collectivity (or more specifically, how the collectivity of protest is formed and reformed), it is necessary to unpack how interaction with other protestors, and their words and deeds, reproduce individual subjectivities in the moment of occupation of a space (Bilgic, 2015a). The reproduction of subjectivities is a consequence of the interaction between the protestors in the home of resistance, where everyday bodily performances of thinking individuals are performed. This not only enables a non-hierarchical political action, but also transforms agonism into solidarity with 'another'. This process does not specifically concern the common 'enemy', be it authoritarian states, neoliberal capitalism, police brutality, or the political transformative practices of collectivity. Instead, it focuses on the reproduction of individual subjectivities through interaction with 'the others'. Through this reproduction, a pluralist collectivity where differences are upheld can be constructed. For example, a LGBTQ member in Gezi stated that:

LGBTQ individuals who participated in the resistance could reach people and make them understand that we are not three eared, five eyed weirdos or freaks... A participant of a 
large soccer fan organization, Çarşı, told one of our trans-friends that he used to swear at prostitutes and transvestites before, but now he will never do that again, since he came to know them and they were able to touch each other (Daloğlu, 2013).

The bodily presence of LGBTQ in the Gezi resistance and their interaction with other protestors had a destabilizing effect on those who used to 'otherize' LGBTQ. Reproduction of subjectivities in the manner of inclusion and empathy towards 'the other' strengthen the multitude. Thinking was not only operational in motivating individuals to protest; the silent dialogue with oneself continued during the moment of resistance. Subjectivities were reproduced to understand 'the other', and the 'other' became 'another' (Booth, 1999: 31). This did not lead to suppression of differences. The Pride march in Istanbul has been also attended by non-members of LGBTQ communities. The stronger the smaller sections or singularities of the multitude are, the stronger and more capable the multitude will be. The emergence and spread of the idea of equality within the multitude provided the foundation of non-hierarchical politics and decision-making. This is also because such political action pushes individuals to understand their shared problems. A protestor from Sytagma reflected on the protest:

The indignados of the Athens movement changed me dramatically and transformed me into an active citizen. In May 2011 the dilemma for me was "sofa and Facebook versus tent and Syntagma". The second alternative won by far, and the results are obvious. Our problems in Greece resemble cholera epidemics. We knew that the problems of the person sitting next to us would soon become our problems. This realization played a significant role in shaping the movement (Voulgarelis, 2012: 172).

Through interaction within the occupied space, individuals understood what it means to be 'the other' and the problems that 'the others' experience. 'The other' becomes just 'another': not an enemy, not an adversary, just 'another' in the network of solidarity among singularities called multitude, which can practice politics non-hierarchically, yet collectively. A protestor from Tahrir said:

During the demonstrations I have seen surprising things: I discovered the huge generosity of Egypt's people. I saw, for example, a guy who loaded his motorcycle with baskets of bread for the demonstrators. Other people came with bags full of taameya and koshari sandwiches. A guy carried boxes of bottled water. Cigarettes were passed hand to hand. And the most impressive thing: people picked up both their own and other people's garbage. Everything was organized so quickly. This is an Egypt I haven't 
seen before, and it's so beautiful to see. This is the first time I have seen a united people sharing food, water, and opinion, despite their differences (quoted in Sampsonia Way, 2011).

This is hardly a description of agonistic politics in Tahrir as 'the home resistance'. They rebuilt their 'home' through everyday performances of equal singularities, which formed the multitude. Transcendence of identity dichotomies does not necessarily mean that pluralism of multiple subjectivities and identities would be suppressed by the multitude. The contemporary protest movements suggest that those who are different can co-exist in solidarity by forming inclusive collectivities. Their horizontal and non-hierarchical political practices are enabled by the realization of this solidarity because of the reproduction of subjectivities in the moment of protest. This even transformed how the resistance can be made. A member of LGBTQ in the Gezi protests states:

I think the masculine protesting style of the left was broken. It showed that it is also possible to protest by saying "Ayyy ayyy" or by reading books. All this may be understood as passive resistance but it turned into something like "we can resist by dancing as well (İşeri and Çetin, 2013).

Both the agonistic politics of radical democracy and multitude, however, fail to understand the importance of everyday performances of protestors in reproducing their subjectivities as members of the multitude and in transforming the squares into homes of resistance. The changes that some protestors experienced in the moment of resistance are the key to understanding how collectivities in pluralism are built in the squares transcending a Schmittian agonism. Furthermore, multitude can be deepen to include individual experiences, which can give this open network a face, and more importantly, enable a multitude form of politics through words and deeds of thinking individuals.

\section{Conclusion}

The conceptual guideline offered in this discussion aims to attract scholars' attention to the three pillars of the contemporary protest movements. Firstly, although they act in collectivity, individuals are the core of these movements. The challenge, however, is how to conceptualize these individuals. The discussion proposes a combination of Arendtian and Butlerian understanding of individuals. In this way, not only the modern and liberal dichotomy between cognitive and body can be 
transcended, but also individuals can be thought without falling the rationalist, liberal, and universalist trap of (neo)liberalism. Secondly, it is vital to conceptualize the role of space as "home of resistance' in new protest movements. The materiality of space offers an identity for such heterogonous groups where they perform politics that challenge, delegitimize, and destabilize neoliberal capitalist, representative politics. The 'everyday' practices of individuals reappropriate the public space for the movement so that its members claim their political visibility. Finally, while both radical democrat and multitude approaches enlighten different dimensions of protesting collectivities, the multitude approach offers a conceptual framework without essentalizing politics with agonism (while not openly rejecting it) and by providing a political guideline of horizontal and non-hierarchical decision-making in line with the human condition of pluralism. That said, the multitude needs human faces to avert the risk of becoming another hegemonic project that subsumes particularities in totality.

\section{Bibliography}

Agathangelou, A.M. and Soguk N. (2013) Introduction: Rocking the Kasbah - Insurrectional politics, the'Arab Streets', and global revolution in the 21st century. In: Agathangelou AM and Soguk N (eds) Arab Revolutions and World Transformations. London \& New York: Routledge, 1-8.

Arendt H. (1998) The Human Condition. Chicago, IL: University of Chicago Press.

Arendt, H. (1971) Thinking and Moral Considerations: A Lecture. Social Research. 38: 3, 417-446.

Arendt, H. (1976) The Origins of Totalitarianism. New York: A Harvest Book.

Badiou, A. (2012) The Rebirth of History: Times of Riots and Uprisings. London and New York: Verso.

Bellver, J. (2012) From New York to Madrid and Back Again. In A. Schiffrin and E. Kircher-Allen (Eds.) From Cairo to Wall Street: Voices from the Global Spring. New York: The New Press, 112-118. 
Benhabib S. (2010) Introduction. In S. Benhabib (Ed.) Politics in Dark Times: Encounters with Hannah Arendt. New York: Cambridge University Press, 1-14.

Berkowitz, R. (2004) Thinking in Dark Times. In R. Berkowitz, J. Katz and T. Keenan (Eds.) Thinking in Dark Times: Hannah Arendt on Ethics and Politics. New York: Fordham University Press, 3-16.

Bilgic, A. (2015a) 'Real people in real places': Conceptualizing power for emancipatory security through Tahrir'. Security Dialogue 46:3, 272-290.

Bilgic, A. (2015b) Hybrid Hegemonic Masculinity of the EU before and after the Arab Spring: A Gender Analysis of Euro-Mediterranean Security Relations. Mediterranean Politics, 1-20.

Blad, C. and Kocer, B. (2012) Political Islam and State Legitimacy in Turkey: The Role of National Culture in Neoliberal State-Building. International Political Sociology, 6:1, 36-56.

Booth K. (2000) Three tyrannies. In T. Dunne and N. Wheeler (Eds.) Human Rights in Global Politics. Cambridge: Cambridge University Press, 31-70.

Brown, D. (2013) Towards a Radical Democracy: The Political Economy of the Budapest School. London: Routledge.

Butler, J. (2011) Bodies in Alliance and the Politics of the Street. \#Occupy Los Angeles Reader.

Daloğlu, T. (2013) LGBT Turks Seek to Capitalize On Gezi Good Will. Al-Monitor, July 02, 2013, http://www.al-monitor.com/pulse/tr/originals/2013/07/turkey-lgbt-gezi.html.

Day, R. and Montgomery N. (2014) Letter to a Greek Anarchist: On Multitudes, Peoples, and New Empires. In A. Kioupkiolis and G. Katsambekis (Eds.) Radical Democracy and Collective Movements Today. Surrey: Ashgate, 45-72.

Dean, J. (2014) Sovereignty of the People. In A. Kioupkiolis and G. Katsambekis (Eds.) Radical Democracy and Collective Movements Today. Surrey: Ashgate, 73-91. 
Douzinas, C. (2010) Athens Revolting. Law Critique, 21, 261-275.

Eileraas, K. (2014) Sex(t)ing Revolution, Femen-izing the Public Square: Aliaa Magda Elmahdy, Nude Protest, and Transnational Feminist Body Politics. Signs. 40:1, 40-52.

Epstain, L. (2012) The Accidental Activist. In A. Schiffrin and E. Kircher-Allen (Eds.) From Cairo to Wall Street: Voices from the Global Spring. New York: The New Press, 189-201.

Farro, A.L. and Demirhisar, D.G. (2014) The Gezi Park Movement: A Turkish Experience of the Twenty-first-century Collective Movements. International Review of Sociology, 24:1, 176-189.

Gordon N. (2002) On visibility and power: An Arendtian corrective of Foucault. Human Studies. 25:2, $125-145$.

Hardt, M. and Negri, A. (2000) Empire. Cambridge: Harvard University Press.

Hardt, M. and Negri, A. (2004) Multitude. New York: Penguin.

Hardt, M. and Negri, A. (2011) The fight for 'Real democracy' at the heart of Occupy Wall Street. Foreign Affairs, 11. Available at https://www.foreignaffairs.com/articles/north-america/2011-1011/fight-real-democracy-heart-occupy-wall-street

Hardt, M. and Negri, A. (2012) Declaration. New York: Argo Nevis.

Harvey, D. (2007) A Brief History of Neoliberalism. Oxford: Oxford University Press.

Hirschkind C. (2012) Interview with Alaa Abd al-Fattah, Tahrir Square, 12 pm, July 19th. Anthropological Quarterly. 85:3, 917-926.

Inceoglu, I. (2014) The Gezi Resistance and its Aftermath: A Radical Democratic Shift?. Soundings: A Journal of Politics and Culture, 57, 23-34. 
Işseri, G. and Çetin, S. (2013) 'LGBT "There is no violence where the state isn't present"', Insan Haber, August 20, 2013, http://everywheretaksim.net/insan-haber-lgbt-there-is-no-violence-where-thestate-isnt-present/.

Laclau, E. and Mouffe, C. (2001) Hegemony and Socialist StrategyTowards a Radical Democratic Politics. New York: Verso, second edition.

Kateb G. (2004) Fiction as Poison. In R. Berkowitz, J. Katz and T. Keenan (Eds.) Thinking in Dark Times: Hannah Arendt on Ethics and Politics. New York: Fordham University Press, 29-41.

Kohn, M. (2013) Privatization and Protest: Occupy Wall Street, Occupy Toronto, and the Occupation of Public Space in a Democracy. Perspectives on Politics. 11:1, pp. 99-110.

Markell, P. (2010) 'The Rule of the People: Arendt, Arche, and Democracy'. In S. Benhabib (Ed.) Politics in Dark Times: Encounters with Hannah Arendt. New York: Cambridge University Press, 58-82.

Mason, P. (2013) Why It is Still Kicking Off Everywhere. New York: Verso.

Mavrammotis, G. (2015) Hannah Arendt in the Streets of Athens. Current Sociology, 63:3, 432-449.

Merz, S. (2013) Reforming Resistance: Neoliberalism and the Co-option of Civil Society Organisations in Palestine. In R. Fisher (Ed.) Managing Democracy Managing Dissent Capitalism, Democracy and the Organisation of Consent. London, Corporate Watch, 136-152.

Mouffe, C. (2005) The Return of the Political. New York: Verson.

Mouheb B. G. (2012) Out from the Behind the Sun, In A. Schiffrin and E. Kircher-Allen (Eds.) From Cairo to Wall Street: Voices from the Global Spring. New York: The New Press, 48-56.

Newman, S. (2014) Occupy and Autonomous Political Life. In A. Kioupkiolis and G. Katsambekis (Eds.) Radical Democracy and Collective Movements Today. Surrey: Ashgate, 93-109 
Paphadjis, F. (2012) No Tears for Greek Democracy. In A. Schiffrin and E. Kircher-Allen (Eds.) From Cairo to Wall Street: Voices from the Global Spring. New York: The New Press, 158-167.

Rancière, J. (2010) The people or the multitudes?. In Dissensus: On Politics and Aesthetics. New York, Continuum, 84-90.

Rashed M.A. (2011) The Egyptian Revolution. Anthropology Today. 27:2, 22-27.

Sampsonia Way (2011) The Egypt I didn't know. 8 February. Available at http://www.sampsoniaway.org /blog/2011/02/08/the-egypt-i-didnt-know/

Sasson-Levy, O. and Rapoport, T. (2003) Body, Gender, and Knowledge in Protest Movements: The Israeli Case. Gender and Society, 17:3, 379-403.

Stiglitz, J. (2012) The World Wakes. In A. Schiffrin and E. Kircher-Allen (Eds.) From Cairo to Wall Street: Voices from the Global Spring. New York: The New Press, 1-22.

Valenzuele, J.M. (2012) A Social Awakening: History of the Protests Against Evictions. In A. Schiffrin and E. Kircher-Allen (Eds.) From Cairo to Wall Street: Voices from the Global Spring. New York: The New Press, 133-140.

Voulgarelis, A. (2012) Nights in Sytagma Square. In A. Schiffrin and E. Kircher-Allen (Eds.) From Cairo to Wall Street: Voices from the Global Spring. New York: The New Press, 168-173.

Waldron, J. (2010) Arendt on the Foundations of Equality. In S. Benhabib (Ed.) Politics in Dark Times: Encounters with Hannah Arendt. New York: Cambridge University Press, 17-38.

Žižek, S. (2008) In Defense of Lost Causes. London and New York: Verso. 